\title{
Archaeological resource modelling in temperate river valleys: a case study from the Trent Valley, UK
}

\author{
A.J. Howard ${ }^{1}$, A.G. Brown ${ }^{2}$, C.J. Carey $^{3}$, K. Challis ${ }^{3}$, L.P. Cooper ${ }^{4}$, \\ M. Kincey ${ }^{3} \&$ P. Toms 5
}

Methods for mapping and determining the condition of archaeological resources while they are still underground have been in development for nearly half a century. The authors here offer an example from the frontiers of the art: the application of a package of remote sensing procedures not only designed to locate sites but to model the valley deposits which contain and cover them. The variation in success of different methods in different deposits offers a guide to the design of evaluation projects on sand and gravel terrain everywhere.

Keywords: Britain, Trent, prehistory, alluvial, floodplain, confluence, lidar, ERGI, geophysics, prospection, bore holes, radiocarbon

\section{Introduction}

Archaeological remains within river valleys are often exceptionally well preserved through a combination of the presence of high water tables, stable terrace surfaces and substantial depths of alluvium (Brown 1997; Howard et al. 2003). However, recent archaeological research focused on British river valleys has shown that both cultural and taphonomic factors influence the wealth and spatial distribution of the archaeological resource across floodplains and terrace surfaces. A number of authors have demonstrated a direct link between the distribution and preservation potential of archaeology and the observed geomorphology (Howard \& Macklin 1999; Passmore et al. 2006). Such patterns of preservation are not unique to the UK and have been observed in Europe (Howard et al. 2004), Africa (Pearl \& Dickson 2004) and North America (Bettis \& Mandel 2002; Bauer et al. 2004). Published studies are not just restricted to empirical observations; recent analytical work within meandering river systems has sought to predict the spatial distribution of archaeology

1 Institute of Archaeology \& Antiquity, University of Birmingham, Edgbaston, Birmingham, B15 2TT, UK (Email: A.J.Howard@bham.ac.uk)

2 School of Geography, University of Southampton, Highfield, Southampton, SO17 1BJ, UK (Email: A.G.Brown@soton.ac.uk)

3 Birmingham Archaeology and VISTA Centre, University of Birmingham, Edgbaston, Birmingham, B15 2TT, UK(Email:C.Carey@bham.ac.uk;K.Challi@@bham.ac.uk;m.e.kincey@bham.ac.uk)

4 University of Leicester Archaeological Services (ULAS), University of Leicester, University Road, Leicester, LE1 7RH, UK (Email: lpc2@le.ac.uk)

5 Department of Natural and Social Sciences, University of Gloucestershire, Swindon Road, Cheltenham, GL50 4AZ,UK (Email: ptoms@glos.ac.uk)

Received: 19 February 2007; Revised: 13 April 2008; Accepted: 23 June 2008

ANTIQUITY 82 (2008): 1040-1054 


\section{A.J. Howard et al.}

on the basis of patterns of erosion and sedimentation, using a landscape evolution model (Clevis et al. 2006).

Archaeological research in Britain has indicated that river confluences and their adjacent floodplains are the focus of prolonged activities. In the Palaeolithic, terrace promontories of higher ground extending into confluence wetlands appear to have formed attractive localities for temporary hunting camps (Wymer 1999). Aerial photography of cropmarks first illustrated the importance of these areas in the Neolithic and Bronze Age for ritual and funerary activity often associated with the deposition of metalwork (Scurfield 1997; Barclay \& Hey 1999; Malim 2000; Brown 2004).

River confluences and their immediate environments are complex, dynamic landscapes, where processes of erosion and sedimentation are extremely variable, reflecting the changing courses of the rivers through time (Best 1988; Bradbrook et al. 2001). The dominant mechanism of floodplain evolution will have an important influence on the preservation potential of the archaeological record. For example, an avulsive system (i.e. one where there is rapid switching of the stream within a pre-existing palaeochannel network, Ashworth et al. 2004) is liable to have a high potential for the preservation of in situ archaeological remains, due to limited channel migration. Such rapid channel movement can also result in the preservation of high densities of organic-rich palaeochannels (Brown 2003). In contrast, river systems that evolve through extensive lateral migration are liable to have a lower potential for the preservation of in situ archaeology. However, even in laterally mobile river systems, active channel migration should not be assumed to lead solely to the destruction of in situ archaeology and even where it does, careful recording of the archaeology can provide valuable information for the reconstruction of floodplain hydrology and human activity (Salisbury et al. 1984; Howard et al. 1999).

Using a case study in the middle Trent Valley (UK), this paper examines the distribution and preservation potential of archaeological resources within a geomorphologically dynamic confluence zone. The complexity of floodplain evolution has necessitated the development of an integrated approach to geoprospection, using a combination of aerial and ground based remote sensing techniques within a GIS framework. Different methodological approaches are required within contrasting geomorphological settings and this paper demonstrates how both natural taphonomic processes as well as human activity within the landscape affect distributions in the archaeological record. Such an approach has generic applicability to other temperate river systems and as such, this paper puts forward some methodological guidelines.

\section{The Trent-Soar valley floor confluence zone}

The confluence zone of the Rivers Trent and Soar (Figures 1 and 2) is a major British river junction, renowned for its rich archaeological record (Knight \& Howard 2004). Quarrying from the turn of the twentieth century led to the early discovery of some archaeological remains, but it was the publication and analysis of aerial photographs of the terrace gravels from the 1960s that provided the first major insight (Cooper 2006). These archaeological remains include a later prehistoric ritual and funerary landscape comprising ring ditches, cursuses, henges, pit circles and a possible mortuary enclosure (Pickering \& Hartley 1985; 


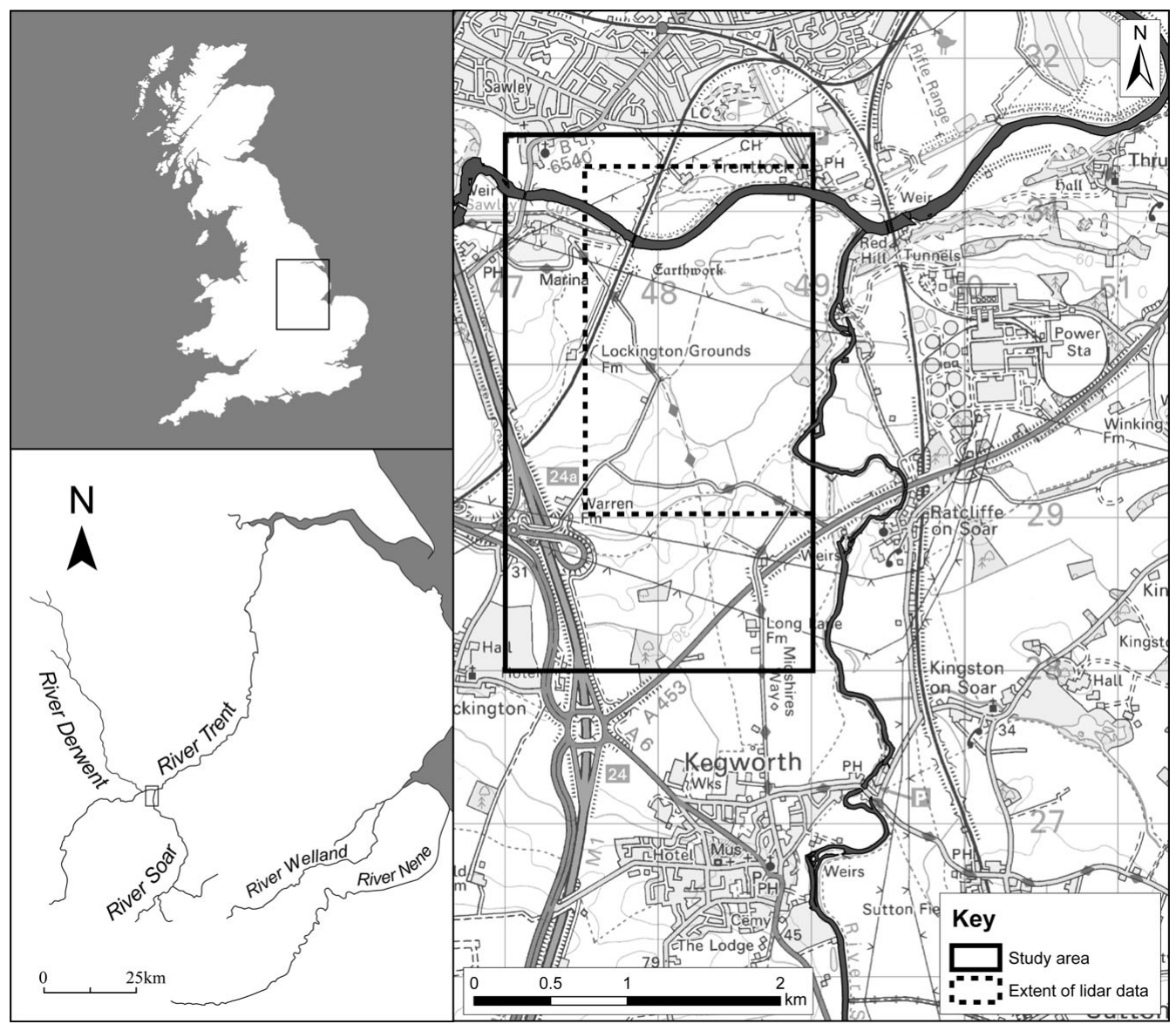

Figure 1. The location of the study area on national, regional and local scales.

Loveday 2004), as well as the Lockington Iron Age and Romano-British settlement and villa complex (Frere \& St Joseph 1983; Pickering \& Hartley 1985). Since the 1980s the confluence and its immediate environs have been the focus of a number of archaeological investigations, in response to quarrying and infrastructure developments, including deskbased, aerial, geophysical, and field surveys which have furthered our knowledge of this historic landscape (see Cooper 2006 and references therein).

In addition to the identification of archaeology on the Pleistocene terraces, significant waterlogged cultural and environmental remains (including large tree trunks) have been recorded buried within and beneath Holocene palaeochannels and sand and gravel deposits (Salisbury 1992). The depth of burial of such archaeological remains renders them largely invisible to conventional methods of surface prospection such as fieldwalking and aerial photography. This point is well illustrated by data from the now exhausted Hemington Quarry, immediately west of the study area, which has produced a wide variety of archaeological finds buried within a 3-4m thick sequence of Holocene sands and gravels. Individual remains include Neolithic to medieval fish-weirs, medieval eel baskets and 


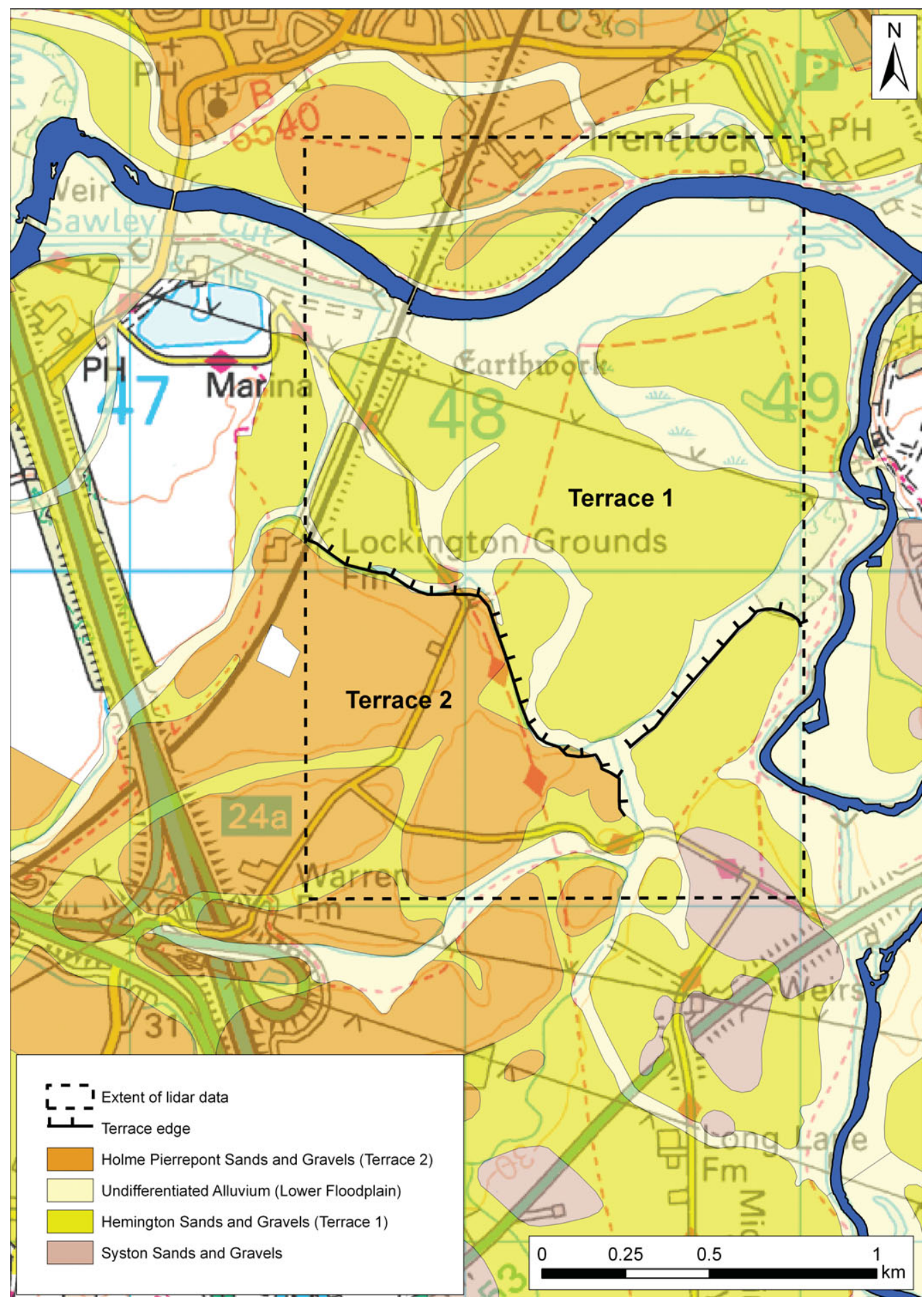

Figure 2. The geological units of the Trent-Soar confluence as defined by the British Geological Survey (BGS). Terrace edges have been added by the authors and it should be noted that in part these do not agree with BGS mapping. 
associated fishing related artefacts; larger structures include a medieval mill-dam and probable mill race, three medieval bridges, and a large fixed engine fishing platform, also of medieval date (Salisbury 1992; Cooper 2003). Other notable remains found locally include Bronze Age log boats at Shardlow Quarry, close to the Trent-Soar confluence (Garton et al. 2001) and several clusters of Bronze Age metalwork, also notably around Shardlow (Scurfield 1997); these latter finds mirror a broader national trend of metal deposition in watery contexts (Bradley 2007). At Elvaston Quarry, close to Shardlow, but on the River Derwent, Bronze Age metalwork has also been recovered from quarry conveyors in association with human and animal remains (Davis 2003).

\section{Methods}

Our new survey project employed a package of innovative technologies to enlarge the archaeological record and identify taphonomic processes. Airborne remotely sensed data was captured using a combination of lidar and standard aerial photography. Lidar has become an established tool for landscape analysis within archaeology with comprehensive reviews provided by Bewley et al. (2005) and Challis (2006). In this study data was captured using a $1 \mathrm{~m}$ data posting. The data set comprised a first pulse digital surface model (FP DSM) and last pulse digital terrain model (LP DTM). The FP DSM produced a model of topography from the first reflective units encountered, including components such as tree canopies, the top of ground vegetation and buildings. The LP DTM produced a model of topography based on a 'bare earth surface', with factors such as vegetation removed. The FP DSM and LP DTM allowed assessment of surface relief and the production of a landform assemblage map (Passmore et al. 2006).

On the ground, a combination of Ground Penetrating Radar (GPR) and Electrical Resistivity (ER; also known as Electrical Resistivity Ground Imaging [ERGI]) was used to investigate three-dimensional sedimentary architecture of terrace and floodplain deposits as well as palaeochannels. GPR was undertaken using a GSSI SIR3000 system with a $200 \mathrm{MHz}$ antenna. ER survey was undertaken using a Syscal Junior 48 electrode system. Geomorphological mapping and auger coring was undertaken to ground-truth the interpretations of all the remote sensing techniques and to provide additional information on sediment stratigraphy. The entire dataset was integrated within a GIS (ArcView version 8.3), with some perspective 3D modelling in ArcScene (version 8.3).

Archaeological data held by Derbyshire and Leicestershire County Councils Historic Environment Records (HERs) was also incorporated within the GIS together with geological data derived from the British Geological Survey (BGS) 1:50 000 field maps. When combined with lidar, this allowed the construction of a terrace sequence model, which allowed zonation of the valley floor into areas of varying geoarchaeological potential.

\section{Results}

The results presented here assess and describe the distribution of the known archaeological resource (now known in UK as the HER or Historic Environment Record) in the context of the geology and geomorphology of the confluence zone. The lidar LP DTM (Figure 3) 

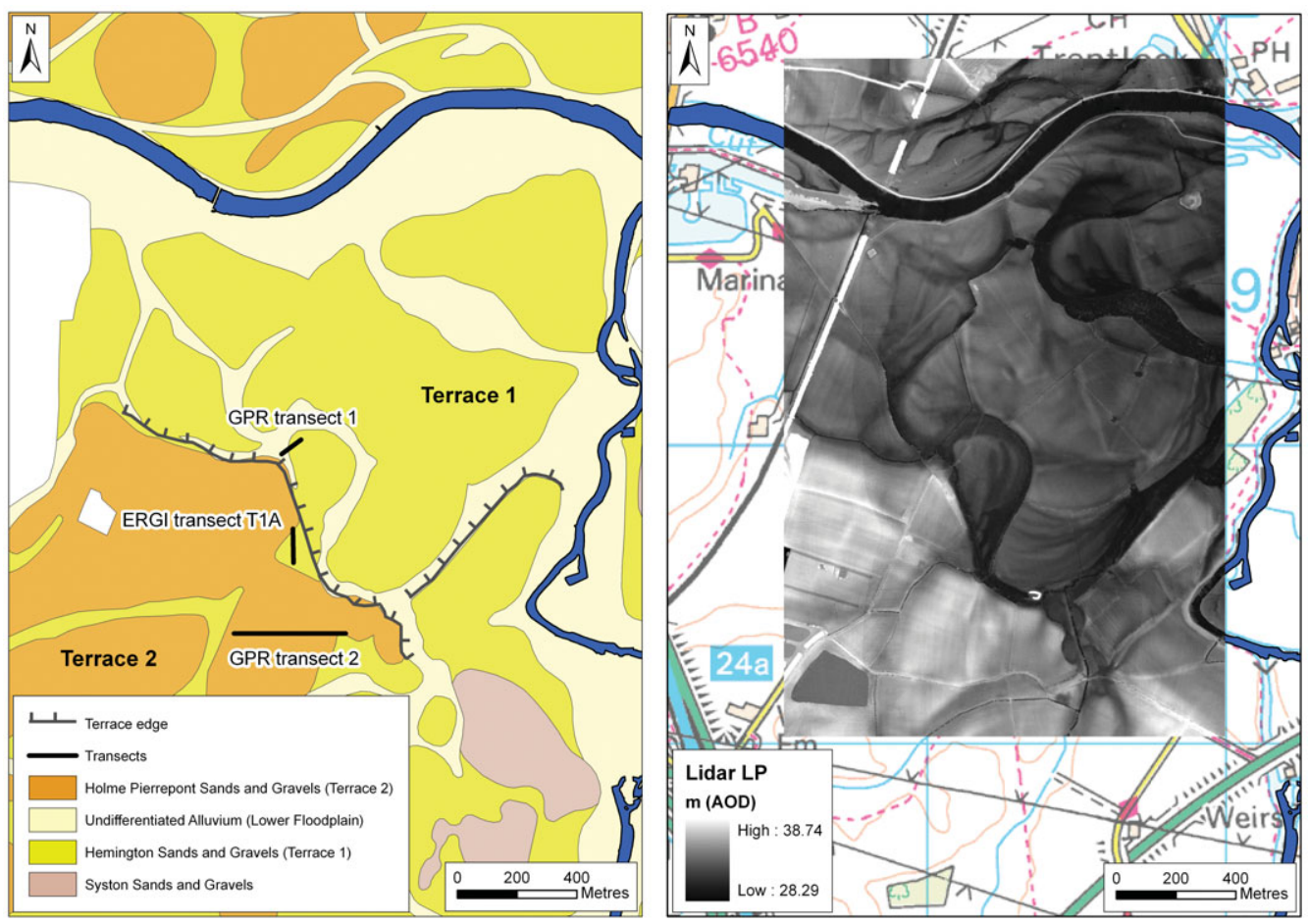

Figure 3. The lidar LP DSM topographic surface model at $50 \%$ transparency compared against the 1:50 000 BGS drift geology map. The locations of geophysical transects 1,2 and T1A are also recorded.

clearly reveals a number of landform assemblages including a relatively recent floodplain, an intermediate terrace (Terrace 1 ) and a higher terrace (Terrace 2 ). This stratigraphy agrees with that produced by the British Geological Survey (BGS), although the lidar imagery identifies significant variations in height across Terrace 1 , as well as a number of palaeochannels traversing the valley floor. Plotting the known archaeological record against the lidar LP DTM (Figure 4), including features identified from geophysics and aerial photography, gives a cluster of 19 sites/find spots on Terrace 2 . This sedimentary unit, termed the Holme Pierrepont Sand and Gravel by the BGS, was deposited by a meltwater-enriched River Trent during the late Devensian, approximately 20-10 Ka BP (Brandon 1996). In contrast, only six HER entries are recorded on Terrace 1 (the Hemington Sand and Gravel) and modern floodplain, which have both developed during the Holocene. Querying of the HER by period (Figure 4) indicated that the majority of known sites on Terrace 2 are prehistoric or Romano-British in age, although any archaeological material from the Late Upper Palaeolithic onwards has the potential to be found on this relatively old, stable terrace. To date, Iron Age and RomanoBritish remains tend to dominate the record of the confluence zone, but this probably represents a disparity in the 'known' record since sites from these periods are often large and easily recognisable from aerial photographs as well as from terrestrial geophysical survey (Figure 4).

Although Terrace 1 has a much smaller number of find spots compared to Terrace 2, a broad age range is again observed, potentially dating back to the Neolithic. This suggests 

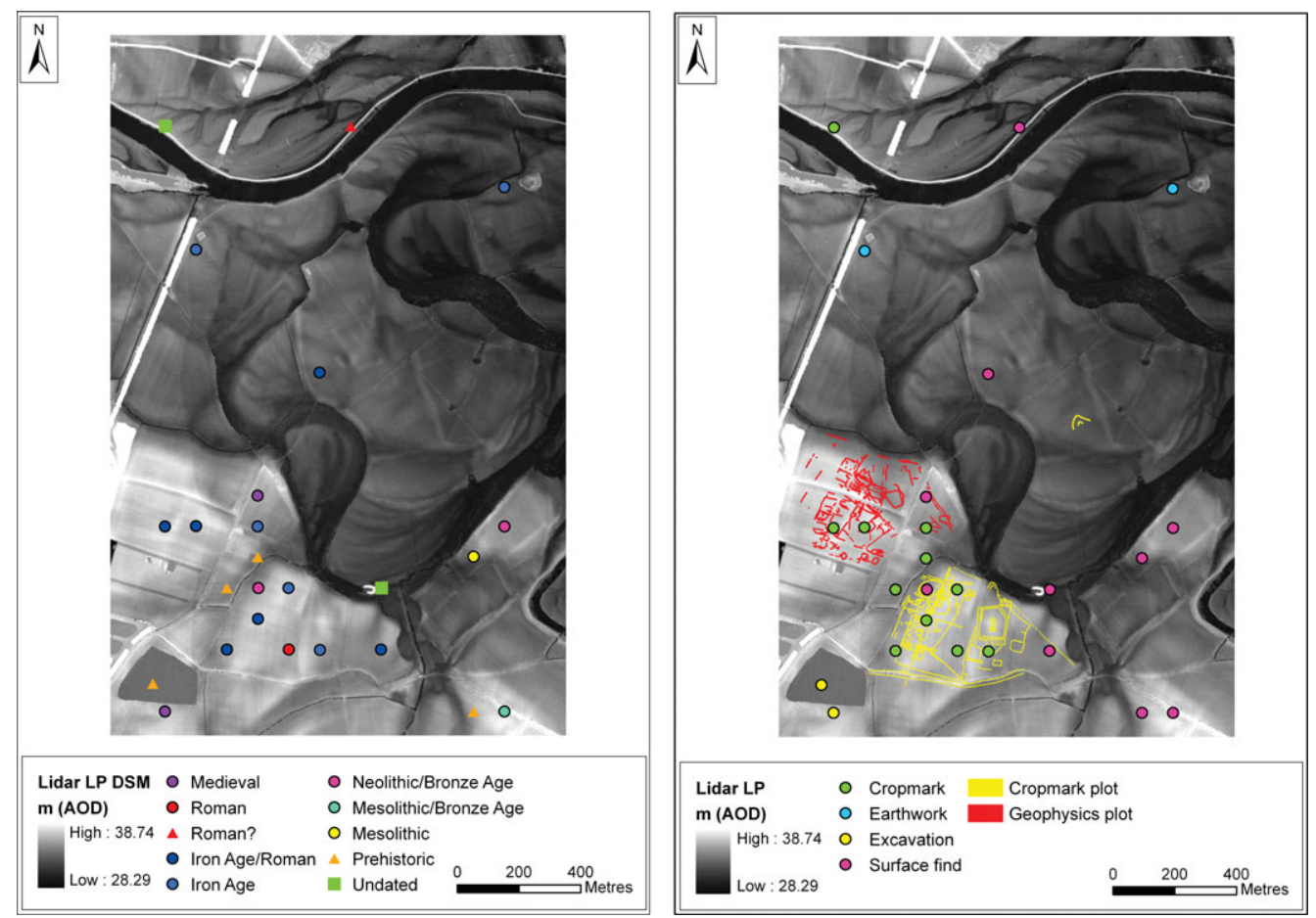

Figure 4. The HER plotted by archaeological period and prospection methodology across the study area.

that Terrace 1 may have been aggraded over an extended period of time, a point corroborated by tree ring dating of bog oaks stratified within the sediments at Warren Farm Quarry in the study area; analyses suggest two chronologies of $c .2700-2600 \mathrm{BC}(\mathrm{n}=3)$ and $c .2500$ BC $(n=1)$ (Arnold et al. 2007). Lidar data indicate around $5 \mathrm{~m}$ of vertical relief across the terrace and it seems probable that different parts of this landsurface were available for occupation at different times. However, such subtle changes in elevation and topography are no longer visible to the naked eye because of erosion and/or further alluviation.

\section{Explaining disparities in archaeological distributions}

Interrogating the HER to determine how archaeological sites were detected produced some significant results and helps to explain the disparities in the known record (Figure 4). All sites identified on Terrace 2 were found through fieldwalking or by aerial photography augmented by geophysical survey, suggesting that the soils are thinly developed across the unit. In contrast, the smaller number of sites identified on Terrace 1 and the floodplain were not generally recorded through fieldwalking and aerial photography, but from exposure of deeper strata. A number of techniques have been used to understand the subsurface stratigraphy of deeply alluviated valley floors. Analysis of borehole logs can provide information concerning deposit thickness, geometry and origin. However, a step change in the resolution of information provided by boreholes can be achieved if they are modelled within a GIS framework and augmented by information collected using selected geophysical techniques (Bates \& Bates 


\section{A.J. Howard et al.}

2000; Challis \& Howard 2003). Recently, Bates et al. (2007) have demonstrated the value of collecting further information from boreholes using selected geotechnical engineering tests (e.g. cone penetration to determine resistance of sediments and hence physical character) as well as through macrofossil analysis. In this study, mineral company borehole records provided relatively coarse stratigraphic information. In order to enhance site stratigraphic data, a combination of GPR and ER was undertaken across selected units. The combination of techniques was required since although GPR is extremely effective within (drier) terrace gravel contexts, the signal is attenuated within fine-grained silts and clays of the floodplain and palaeochannels (Vandenberghe \& Overmeeren 1999). In these latter environments, ER allowed the recognition of fine grained stratigraphy (Baines et al. 2002).

GPR data collected across Terrace 2 confirmed that the soils are shallow (around $0.4 \mathrm{~m}$ thick) and overlie braided river gravels, a point exemplified by GPR Transect 2, Terrace 2 (Figure 5; see Figure 3 for location). The shallow nature of the soils suggests that the visibility of the archaeological resource is intimately linked to its preservation status; archaeology on these shallow soils is almost certainly within the plough zone and hence the focus of destruction, a point emphasised by the significant amount of material collected through fieldwalking.

GPR survey across Terrace 1 and the modern floodplain revealed between $0.75 \mathrm{~m}$ and $1.5 \mathrm{~m}$ of fine-grained alluvium (Figure 5, Transect 1; see Figure 3 for location). This greater thickness of alluvium on Terrace 1 helps to explain the fewer number of sites identified either as cropmarks or through fieldwalking. Whilst thicker alluvium hinders geoprospection, it may bury and protect sites from plough damage. The thicker deposits of alluvium and higher groundwater tables across Terrace 1 and the floodplain reduced the capability of GPR (through attenuation of the signal), allowing only the broad geometry and character of the deposits to be recorded, providing little finer stratigraphic detail. The internal characteristics of the thicker sequences of alluvium were further complicated by the presence of major palaeochannels, which contained significant organic-rich fills. To elucidate the internal structure of these sequences of alluvium and channel fills a series of ER transects were undertaken across the contrasting terrain units (i.e. adjacent terrace-floodplain-channel surfaces). Testing of the interpretation of ER data against the results of hand augering demonstrated that ER was extremely effective at delimiting the gross morphology of the palaeochannels, defining their depth and cross-sectional geometry and provided additional information via resistivity values, on the wetness and hence preservation potential of their fills.

ERGI Transect T1A investigated a palaeochannel on Terrace 1 (Figure 6; see Figure 3 for location) identified from the lidar LP DTM. The ER cross section is shown alongside stratigraphy derived from gouge core survey and also a corresponding GPR section. This palaeochannel is somewhat anomalous within the study area, with a deep fill $(c .4 \mathrm{~m})$ above gravels. Internally, the stratigraphy of the feature was complex, comprising several discrete sediment units. The GPR transect clearly demonstrates the limitation of using this technique when investigating water-saturated/clay-rich palaeochannels. The terrace gravels are definable at the start of the GPR transect, but as soon as the edge of the palaeochannel is encountered the technique produces no interpretable data. In contrast, the ER transect defines the two major units of the terrace (high resistivity units A and B) and 
GPR transect 1
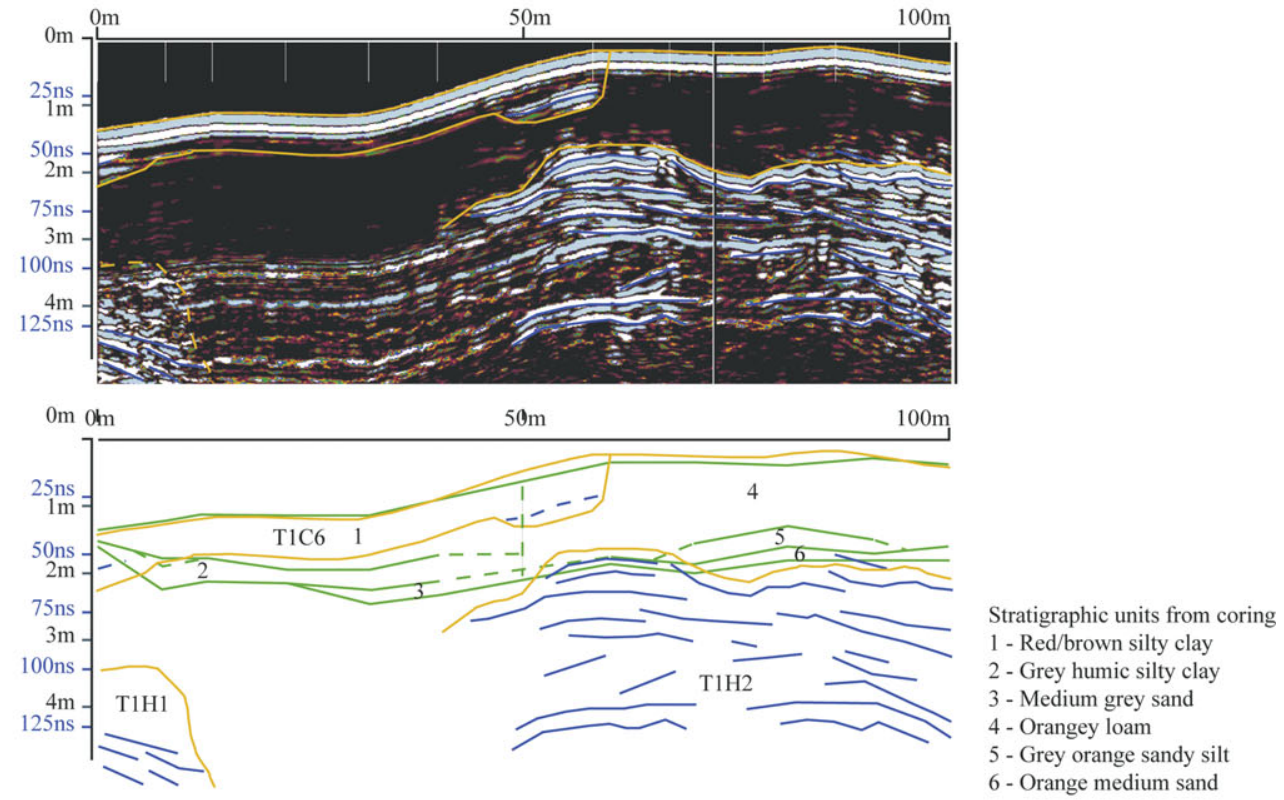

GPR transect 2
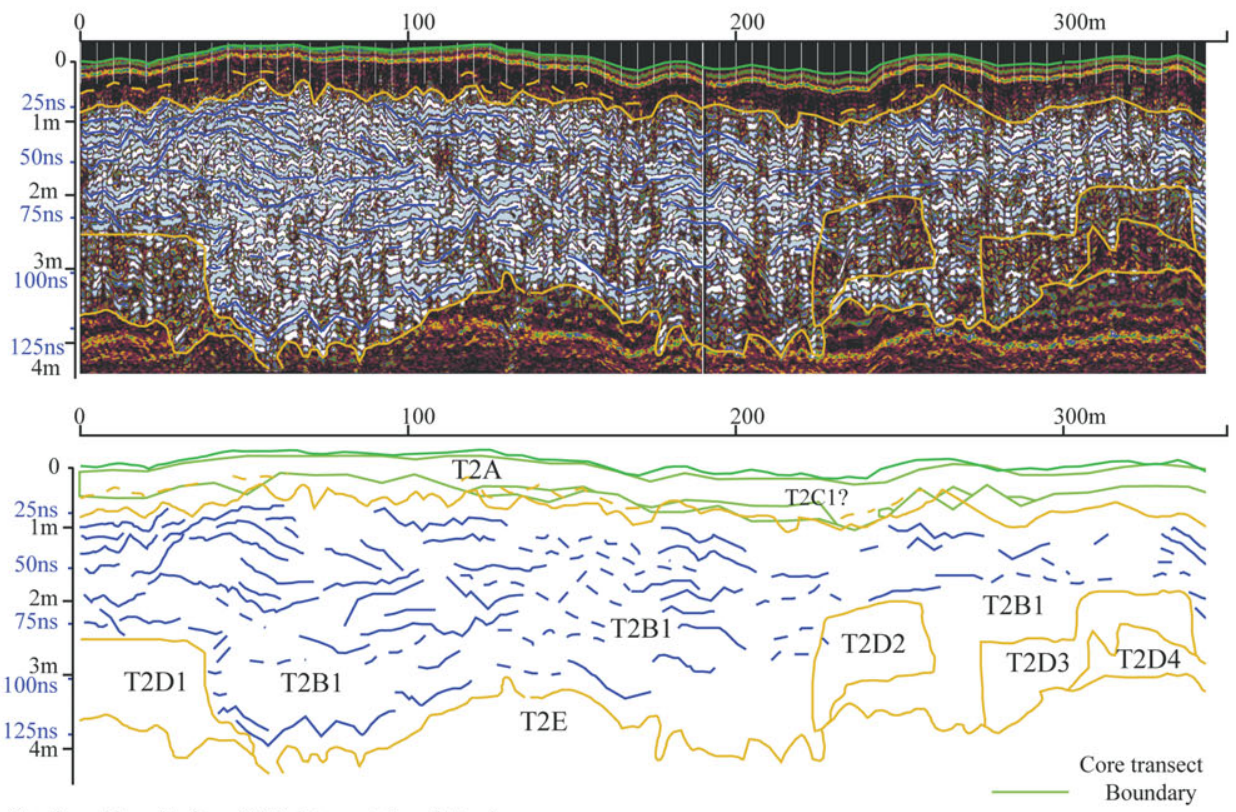

Stratigraphic units from GPR interpretation (letters):

$\mathrm{T} 2 \mathrm{~A}$ - alluvium

T2B1 - gravel unit, higher reflection

$\mathrm{T} 2 \mathrm{C}$ (number) - palaeochannel

GPR interpretation

T2D(number) - gravel unit lower reflection

T2E - bedrock

Strong reflecting layer

Sedimentary boundary

- - Suggested reflecting layer

- - Suggested sedimentary boundary

Figure 5. GPR transects 1 and 2, with interpretation of stratigraphy. 


\section{A.J. Howard et al.}

\section{Transect T1A}

A) GPR section with gouge core stratigraphy

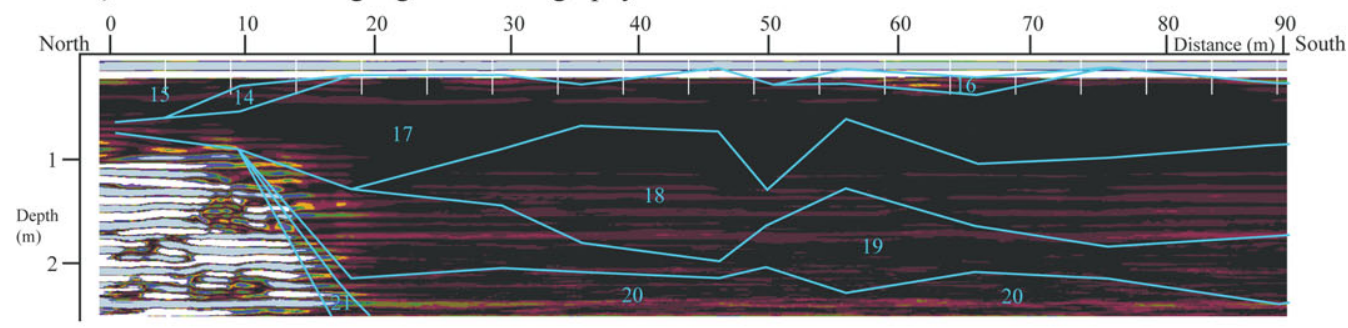

B) ER section with gouge core stratigraphy

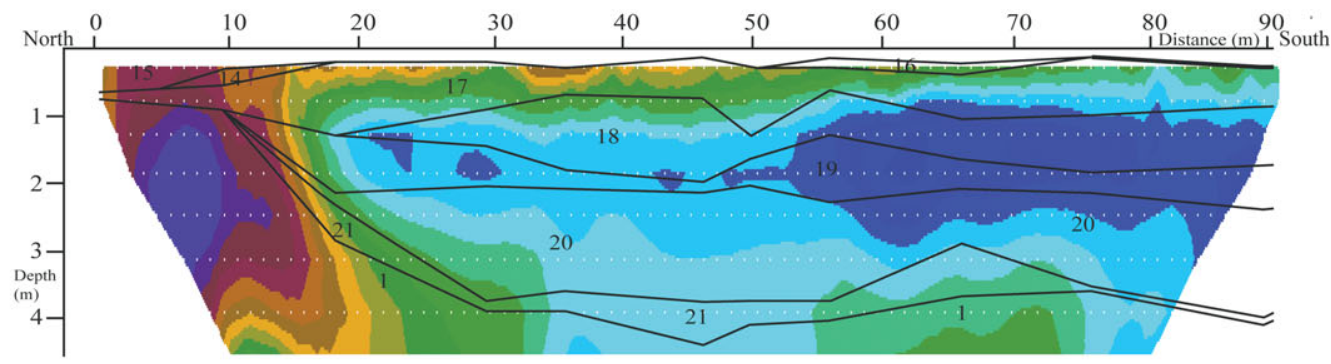

C) ER section with interpretation

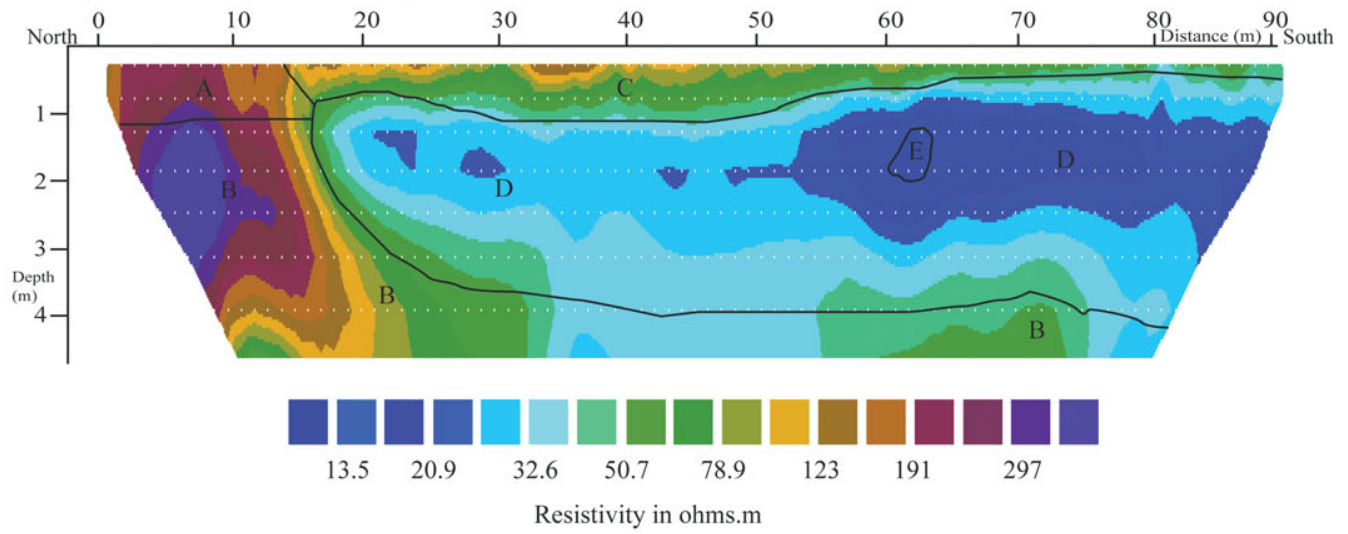

Key for interpretation:

$\mathrm{A}=$ alluviuam above gravel (silty clay)

$\mathrm{B}=$ gravels

$\mathrm{C}=$ alluvium above palaeochannel fill

$\mathrm{D}=$ palaeochannel

$\mathrm{E}=$ area of lowest resistance within

palaeochannel
Key gouge core stratigraphy:

$1=$ inpenetrable gravel

$2=$ pink/grey mottled medium sand

$3=$ stiff mottled grey/yellow/orange clay

$4=$ yellow/orange sandy silt clay

$5=$ pure medium yellow sand

$6=$ organic rich dark grey sand

$7=$ red brown clayey sand

$8=$ medium brown clayey sand

$9=$ blue grey clay with sand

$10=$ blue grey clay with peaty matrix

$11=$ fine olive/grey clay sand with organics
$12=$ blue/grey sand medium

$13=$ wood rich dark grey fine/medium sand

$14=$ silty brown clay, trace of sand, charcoal flecks

$15=$ red brown silt with sand and clay (loam)

$16=$ orange brown silt

$17=$ orange brown sandy clay

$18=$ blue grey gleyed clay with $\mathrm{Fe}$ and Mn mottling

$19=$ blue grey clay

$20=$ olive brown dark grey clay

$21=$ olive brown/dark grey medium sand

Figure 6. The ERGI results from transect T1A. 
the palaeochannel (low resistivity units $\mathrm{C}$ and $\mathrm{D}$ ). The interface between the fine-grained alluvium and the top of the gravels and also the stratification within the palaeochannel, is not precisely defined from the ER section, although much information is derived on gross morphology of the alluvial sequence, which correlates with the gouge core stratigraphic data. The palaeochannel sediment units defined by gouge coring are not identifiable as discrete entities within the ER section; of these, unit 20 (olive brown dark grey clay) and unit 19 (blue grey clay) were recorded as having high organic preservation potential. The silt and sand clay units in the upper part of the palaeochannel are partly identified as unit $\mathrm{C}$ (alluvium). The area of lowest resistivity within the palaeochannel is unit $\mathrm{D}$. Therefore, the application of ER within this study proved its value for the geoprospection of fine-grained palaeochannel fills, identifying the depth of the features, as well as some indication of preservation potential. The resolution of data provided by undertaking multiple transects across the study area is high and allows the identification of areas such as palaeochannel segments where suitable samples are likely to be recovered for further environmental analysis and radiometric dating.

\section{Development of a chronological framework}

Interrogation of the archaeological, geological and landform assemblage datasets within a GIS allows the construction of a terrace sequence model that also serves as a map of archaeological potential. The lidar LP DTM provides a relative-age model based on the topographic heights between the geomorphological units. Whilst relative age frameworks are exceedingly valuable, high-resolution chronological control can only be achieved through the development of a radiometric-dating framework.

For the majority of research projects dealing with the Late Pleistocene and Holocene, this is usually achieved using radiocarbon techniques with due consideration of the problems of plateaux in certain time periods (Guilderson et al. 2005). To an extent, these chronological problems are being overcome by interrogating multiple radiocarbon datasets using advanced statistical methods, most notably Bayesian modelling (e.g. Buck \& Blackwell 2004). Increasingly, with respect to alluvial archaeological studies, other methods are being considered, which can also deal with longer timescales. Of particular note is the application of luminescence dating to quartz-rich sediments (Duller 2004), though this technique is still the focus of methodological development, particularly relating to re-zeroing of the luminescence clock (Rodnight et al. 2006).

Within this study a combination of (AMS) radiocarbon and Optically Stimulated Luminescence (OSL) methods were applied to sediments extracted from undisturbed sediment cores (collected using a Geoprobe). AMS radiocarbon techniques were applied to organic material collected from the basal and uppermost organic horizons within the palaeochannels to provide an indication of the timing of channel activation and abandonment. In contrast, OSL samples were recovered from bar-top localities (beneath alluvium), immediately adjacent to palaeochannels in an attempt to provide an indication of channel migration (Figure 7). This chronological data is reported fully elsewhere (Hamilton et al. 2008), but the broad trends of the data are also summarised visually in Figure 7.

Terrace 2 represents a stable landsurface of considerable antiquity and offers the potential to preserve multi-period archaeological remains (i.e. Upper Palaeolithic to post-medieval). 

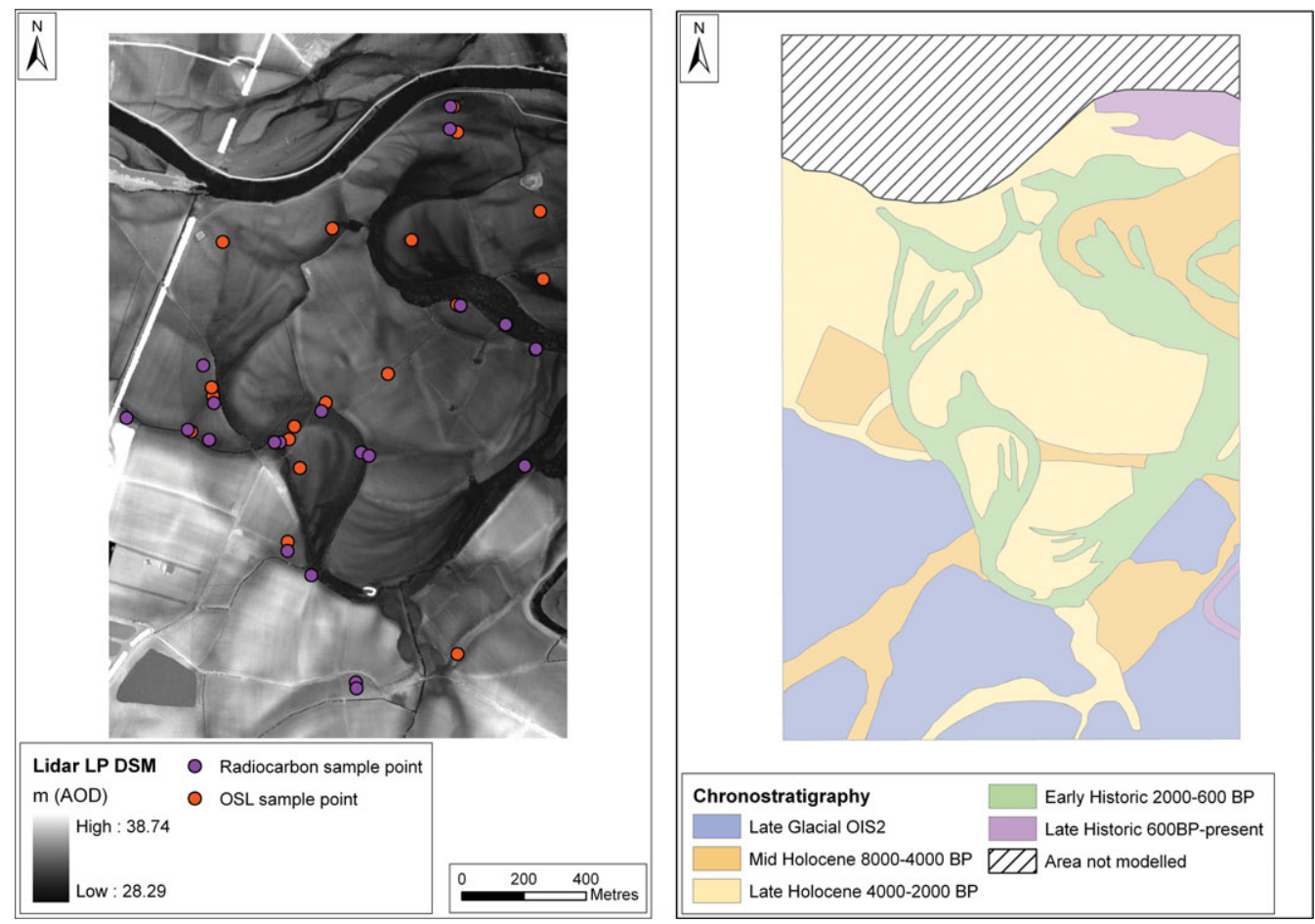

Figure 7. The location of radiocarbon and OSL sample points across the study area, the results of which were used to construct a terrace sequence model, thereby allowing the valley floor to be zoned into areas of varying archaeological potential.

In contrast, the sands and gravels of Terrace 1 were aggraded from the Neolithic onwards with significant fine-grained alluviation commencing in the Bronze Age. Despite the absence of significant 'visible' archaeological remains across Terrace 1 there is the possibility of burial of prehistoric and younger deposits in what would have previously been considered 'blank' areas. Since parts of Terrace 1 extend back to the Neolithic, this may include evidence for ritual and funerary activity traditionally recorded and prospected for across Terrace 2 .

Furthermore, dating indicates that the palaeochannels that dissect Terrace 1 and the floodplain are substantially younger than the underlying sands and gravels and indicate a predominantly avulsive (i.e. scouring) model of confluence evolution, with the channels periodically reoccupied and abandoned. Whilst there is some evidence of lateral meander migration visible on the LP DSM, it is clear that most migration has been constrained to a series of palaeochannel corridors dissecting the terrace surface. Together, this evidence suggests that preservation potential will be high.

\section{Towards a generic methodology}

Using the case study of the Trent-Soar confluence, this paper demonstrates that adopting a multi-methodological approach to archaeological prospection combining both airborne and ground-based geophysical remote sensing technologies, linked to more traditional field survey (both geomorphological and archaeological) is essential to understand the spatial 
pattern of valley floor archaeological records. Traditional approaches to airborne remote sensing have focused on aerial photography, but this is now being enhanced by digital elevation data captured using lidar, and to a lesser extent IFSAR (Challis 2006) and satelliteborne photographic imagery such as Corona (Alizadeh \& Ur 2007). Where disparities in the known archaeological record are apparent, it is essential to investigate beneath the ground surface and assess both the three-dimensional stratification, origin and postdepositional history of the sediments. Whilst some geophysical techniques such as resistivity and magnetometry have a long history of application for archaeological prospection (Gaffney $\&$ Gater 2003) increasing emphasis is being placed on the utilisation of other techniques such as GPR and ER. However, this study demonstrates that an awareness of ground conditions, particularly with respect to grain size and water tables are essential if these techniques are to be used to their full potential. Furthermore, high-resolution models of landscape development require radiometric-dating control. The collection of such large quantities of data requires significant storage and interactive analysis within a GIS. This project used ARC-GIS but a number of other products are available on the market; before deciding on what product to use, consideration should be given to the final repository for archaeological data and compatibility of systems.

In this study, combining archaeological data within a chronostratigraphic framework has provided the opportunity to critically examine the distribution of archaeology within the confluence zone by both geomorphological and age factors. This effectively provided an archaeological risk map, which zoned the valley floor into areas of high and low potential. Furthermore, it indicates that the development of strategies for archaeological prospection need to be tailored to contrasting parts of the landscape and requires a staged approach (Cooper 2006). Whilst fieldwalking and analysis of aerial photographs will undoubtedly lead to the identification of further sites on the Pleistocene terraces where soils are relatively thin, these methods are unlikely to identify new sites on the thickly alluviated surface of Terrace 1 or the modern floodplain. Across these latter surfaces, subsurface prospection using a combination of coring, test pitting and selected geophysics, such as GPR and ER will provide more robust methodologies.

\section{Conclusion}

Significant research over the past few decades has demonstrated the archaeological wealth of the Trent-Soar confluence. However, the complex evolution of this landscape and others of similar character necessitates the development of innovative approaches to geoarchaeological prospection and archaeological mitigation. This paper has demonstrated that a tool-kit based on airborne and ground-based remote sensing technologies combined with elements of more traditional field survey can be effective. Lidar survey produced a high-resolution topographic model and associated landform assemblage map, which, when combined with information collected from subsurface strata using GPR and ER provided a powerful tool for elucidating landscape evolution and assessing the role of geological filtering (Bettis \& Mandel 2002) and other taphonomic processes affecting the preservation of archaeological remains. The dynamic evolution of the river system around this confluence has undoubtedly eroded and truncated much of the archaeological resource, but has also been an agent of preservation, 
sealing sites both beneath and within fine-grained alluvium and by burying them within sands and gravels deposited by laterally migrating and/or avulsing river channels.

The chronostratigraphic terrace sequence model when dovetailed with the archaeological record provides an important tool for cultural resource management and the development of mitigation strategies. This combined approach has generic applicability to other temperate river systems around the globe.

\section{Acknowledgements}

This project was financed via the ALSF (PNUM 3357). Thanks are due to Dr Jen Heathcote, Helen Keeley and Dr Peter Marshall of English Heritage for help and advice. Derbyshire and Leicestershire HERs are thanked for providing information on known archaeological sites and Robert Howard (NTRDL) undertook dendrochronological analyses. Mr Charles Coker and his tenant farmers generously provided land access on numerous occasions. La Farge Aggregates Ltd is thanked for permission to work in Warren Farm Quarry and its continual support of archaeological work funded via PPG 16. The comments of Dr Patrick Clay and a second anonymous referee are gratefully acknowledged for improving the clarity of this manuscript.

\section{References}

AlizadeH, K. \& J.A. UR. 2007. Formation and destruction of pastoral and irrigation landscapes on the Mughan Steppe, north-western Iran. Antiquity 81: 148-60.

ARNOLD, A., R. HOWARD \& C. LiTTON. 2007. Warren Farm Quarry, Lockington Leicestershire. Tree ring analysis of timbers (English Heritage Research Department Report Series 101-2007), Fort Cumberland, Portsmouth.

Ashworth, P.J., J.L. Best \& M. Jones. 2004. Relationship between sediment supply and avulsion frequency in braided rivers. Geology 32: 21-4.

Baines, D., D.G. Smith, D.G. Froese, P. Bauman \& G. NIMECK. 2002. Electrical resistivity ground imaging (ERGI): a new tool for mapping the lithology and geometry of channel-belts and valley-fills. Sedimentology 49: 441-9.

Barclay, A. \& G. Hey 1999. Cattle, cursus monuments and the river: the development of ritual and domestic landscapes in the upper Thames Valley, in A. Barclay \& J. Harding (ed.) Pathways and ceremonies: the cursus monuments of Britain and Ireland (Neolithic Studies Group Seminar Papers 4): 67-76. Oxford: Oxbow.

BATES, M.R. \& C.R. BATES. 2000. Multi-disciplinary approaches to the geoarchaeological evaluation of deeply stratified sedimentary sequences: examples from Pleistocene and Holocene deposits in southern England, United Kingdom. Journal of Archaeological Science 27: 845-58.

Bates, M.R., C.R. BATES \& J.E. WhitTAKer. 2007. Mixed method approaches to the investigation and mapping of buried Quaternary deposits: examples from southern England. Archaeological Prospection 14: 104-29.
Bauer, A., K. Nicoll, L. Park \& T. Matney. 2004. Archaeological site distribution by geomorphic setting in the southern lower Cuyahoga river valley, north-eastern Ohio: initial observations from a GIS database. Geoarchaeology 19(8): 711-29.

BEST, J. 1988. Sediment transport and bed morphology at river channel confluences. Sedimentology 35(3): 481-98.

BetTis, E.A. \& R.D. MANDEL. 2002. The effects of temporal and spatial patterns of Holocene erosion and alluviation on the archaeological record of the Central and Eastern Great Plains, USA. Geoarchaeology 17(2): 141-54.

Bewley, R.H., S.P. CrutChley \& C.A. Shell. 2005. New light on an ancient landscape: lidar survey in the Stonehenge World Heritage Site: Antiquity 79: 636-47.

BradbroOK, K.F., S.N. LANE, K.S. Richards, P.M. BIRON \& A.G. RoY. 2001. Role of bed discordance at assymetrical river confluences. Journal of Hydraulic Engineering 127: 351-68.

BRADLEY, R. 2007. The prehistory of Britain and Ireland. Cambridge: Cambridge University Press.

Brandon, A. 1996. Geology of the Lower Derwent Valley. 1:10 000 sheets SK 33SE, 43SW \& 43SE, part of 1:50 000 sheets 141 (Loughborough) (Onshore geology series technical report WA/96/07). Keyworth: British Geological Survey.

BROWN, A.G. 1997. Alluvial environments: geoarchaeology and environmental change. Cambridge: Cambridge University Press.

-2003. Time, space and causality in floodplain palaeoecology, in A.J. Howard, M.G. Macklin \& D.G. Passmore (ed.) Alluvial archaeology in Europe: 15-26. Rotterdam: Swets \& Zeitlinger. 
-2004. Divisions of floodplain space and sites on riverine 'islands': functional, ritual, social, or liminal places? Journal of Wetland Archaeology 3: 3-16.

BuCK, C.E. \& P.G. BlaCKWELL. 2004. Formal statistical models for estimating radiocarbon calibration curves. Radiocarbon 46(3): 1093-1102.

Challis, K. 2006. Airborne laser altimetry in alluviated landscapes. Archaeological Prospection 13: 103-27.

Challis, K. \& A.J. HowARD. 2003. GIS based modelling of sub-surface deposits for archaeological prospection in alluvial landscapes, in A.J. Howard, M.G. Macklin \& D.G. Passmore (ed.) Alluvial archaeology in Europe: 263-75. Rotterdam: Swets \& Zeitlinger.

CoOper, L.P. 2003. Hemington Quarry, Castle Donington, Leicestershire, UK: a decade beneath the alluvium in the confluence zone, in A.J. Howard, M.G. Macklin \& D.G. Passmore (ed.) Alluvial archaeology in Europe: 27-41. Rotterdam: Swets \& Zeitlinger.

-2006. Archaeological assessment of the Trent-Soar confluence zone. Transactions of the Leicestershire Archaeological and Historical Society 80: 1-25.

DAVIS, R. 2003. A Bronze shield fragment and spearhead from Elvaston Quarry, Derbyshire. Derbyshire Archaeological Journal 123: 63-70.

DULLER, G.AT. 2004. Luminescence dating of Quaternary sediments: recent advances. Journal of Quaternary Science 19(2): 183-92.

Frere, S.S. \& J.K. ST. JosEPH. 1983. Roman Britain from the air. Cambridge: Cambridge University Press.

GAFFNEY C. \& J. GATER. 2003. Revealing the buried past: geophysics for archaeologists. Stroud: Tempus.

Garton, D., L. Elliott \& C.R. Salisbury. 2001. Aston upon Trent, Argosy Washolme. Derbyshire Archaeological Journal 121: 196-200.

Guilderson, T.P., P.J. Reimer \& T.A. Brown. 2005. The boom and bane of radiocarbon dating. Science 307: 362-4.

Hamilton, W.D., P.D. Marshall, R. Howard, P. Toms, T. Brown, C. Carey, C. Bronk-Ramsey, J. VAN DER Plicht \& G. COOK. 2008. Evaluating a multiple chronometric approach to dating palaeoconfluences. Unpublished report, English Heritage.

Howard, A.J. \& M.G. MaCKLIN. 1999. A generic geomorphological approach to archaeological interpretation in British river valleys: a guide for archaeologists investigating Holocene landscapes. Antiquity 73: 527-41.

Howard, A.J., D.N. Smith, D. Garton, J. Hilliam \& M. PEARCE. 1999. Middle to late Holocene environments in the middle to lower Trent Valley, in A.G. Brown \& T. Quine (ed.) Fluvial processes \& environmental change: 165-78. Chichester: Wiley.
Howard, A.J., M.G. Macklin \& D.G. PAssmore (ed.). 2003. Alluvial archaeology in Europe. Rotterdam: Swets \& Zeitlinger.

Howard, A.J., M.G. Macklin, D.W. Bailey, S. Mills \& R. ANDREESCU. 2004. Late Glacial and Holocene river development in the Teleorman Valley on the southern Romanian Plain. Journal of Quaternary Science 19(3): 271-80.

Knight, D. \& A.J. Howard. 2004. Trent Valley landscapes: the archaeology of 500,000 years of change. Kings Lynn: Heritage Marketing \& Publications.

LOVEDAY, R. 2004. Contextualising monuments: the exceptional potential of the Middle Trent Valley. Derbyshire Archaeological Journal 124: 1-12.

Malim T. 2000. The ritual landscape of the Neolithic and Bronze Age along the middle and lower Ouse Valley, in M. Dawson (ed.) Prehistoric, Roman and post-Roman landscapes of the Great Ouse Valley (CBA Research Report 119): 57-88. York: Council for British Archaeology.

Passmore, D.G., C. WAdDington \& T. VAN DER SCHRIEK. 2006. Enhancing the evaluation and management of river valley archaeology: geoarchaeology, in the Till-Tweed catchment, northern England. Archaeological Prospection 13: 269-81.

Pearl, F.B. \& D.B. Dickson. 2004. Geoarchaeology and prehistory of the Kipsing and Tol river watersheds in the Mukogogo Hills region of Central Kenya. Geoarchaeology 19(6): 565-82.

PiCKering, J. \& R.F. Hartley. 1985. Past worlds in a landscape (Archaeological Reports Series 11). Leicester: Leicestershire Museums, Art Galleries and Records Service.

Rodnight, H., G.A.T. Duller, A.G. Wintle \& S. Tоотн. 2006. Assessing the reproducibility and accuracy of optical dating of fluvial deposits. Quaternary Geochronology 1: 109-20.

SALISBURY, C.R. 1992. The archaeological evidence for palaeochannels in the Trent Valley, in S. Needham \& M.G. Macklin (ed.) Alluvial archaeology in Britain (Oxbow Monograph 27): 155-62. Oxford: Oxbow.

Salisbury, C.R., P.J. Whitley, C.D. LitTon \& J.L. Fox. 1984. Flandrian courses of the River Trent at Colwick, Nottingham. Mercian Geologist 9: 189-207.

SCURFIELD, C. 1997. Bronze Age metalwork from the River Trent in Nottinghamshire. Transactions of the Thoroton Society of Nottinghamshire 101: 29-57.

VANDENBERGHE, J. \& R.A. OVERMEEREN. 1999. Ground penetrating radar images of selected fluvial deposits in the Netherlands. Sedimentary Geology 128: 245-70.

WyMer, J.J. 1999. The Lower Palaeolithic occupation of Britain. Salisbury: Trust for Wessex Archaeology \& English Heritage. 